\title{
Integrins functioning in uterine endometrial stromal and epithelial cells in estrus
}

\author{
Hye Jin Park¹, Ji Eun Park¹, Hyun Lee, Seong Jae Kim', Jung Im Yun², Minseok Kim³, \\ Kyu Hyun Park ${ }^{2}$ and Seung Tae Lee Le $^{1,4}$ \\ ${ }^{1}$ Department of Animal Life Science, Kangwon National University, Chuncheon, Korea, ${ }^{2}$ Division of Animal \\ Resource Science, Kangwon National University, Chuncheon, Korea, ${ }^{3}$ Animal Nutrition and Physiology Team, \\ National Institute of Animal Science, RDA, Wanju, Korea and ${ }^{4}$ Division of Applied Animal Science, \\ Kangwon National University, Chuncheon, Korea \\ Correspondence should be addressed to ST Lee; Email: stlee76@kangwon.ac.kr
}

\begin{abstract}
Here, as a basic study in the construction of a non-cellular niche that supports artificial organization of three-dimensional endometrial tissue, we defined the types of integrin heterodimers that are expressed transcriptionally, translationally and functionally in endometrial stromal (ES) and endometrial epithelial (EE) cells isolated from the mouse uterus in estrus. Gene and protein expression of integrin subunits were analyzed at the transcriptional and translational level by real-time PCR and fluorescent immunoassay, respectively. Moreover, the functionality of integrin heterodimers was confirmed by attachment and antibody inhibition assays. Itga2, Itga5, Itga6, Itga9, Itgav, Itgb1, Itgb3 and Itgb5 in ES cells, and Itga2, Itga5, Itga6, Itga7, Itga9, Itgav, Itgb1, Itgb3, Itgb4, Itgb5 and Itga6 and in EE cells showed significantly higher transcriptional levels than the other integrin subunits. Furthermore, translational expression of the total integrin $\alpha$ and $\beta$ subunit genes that showed increased transcription was determined in ES and EE cells. ES cells showed significantly increased adhesion to collagen I, fibronectin and vitronectin, and functional blocking of integrin $\alpha_{2}$, $\alpha_{5}$ or $\alpha_{V}$ significantly inhibited adhesion to these molecules. Moreover, EE cells showed significantly increased adhesion to collagen I, fibronectin, laminin and vitronectin, and functional blocking of integrin $\alpha_{2}, \alpha_{5}, \alpha_{6}$ or $\alpha_{V}$ significantly inhibited adhesion to these molecules. Accordingly, we confirmed that integrin $\alpha_{2} \beta_{1}, \alpha_{5} \beta_{1}, \alpha_{v} \beta_{1}, \alpha_{v} \beta_{3}$ and/or $\alpha_{v} \beta_{5}$, and integrin $\alpha_{2} \beta_{1}, \alpha_{5} \beta_{1}, \alpha_{6} \beta_{1}$ and/or $\alpha_{6} \beta_{4}$ $\alpha_{\sqrt{v}} \beta_{1}, \alpha_{v} \beta_{3}$ and/or $\alpha_{\sqrt{v}} \beta_{5}$, actively function on the surface of ES and EE cells from mouse uterus in estrus phase, respectively. Reproduction (2017) 153 351-360
\end{abstract}

\section{Introduction}

Uterine endometrial stromal (ES) and endometrial epithelial (EE) cells undergo dynamic periodic alterations during the reproductive period (Chan et al. 2004, Schwab et al. 2005). This is particularly evident during the estrus cycle, when the endometrium undergoes histological and functional remodeling (Tang et al. 2005, Arai et al. 2013), resulting in an increase in the receptivity of the endometrium to embryos (Ponsuksili et al. 2012, Chadchan et al. 2016). Therefore, during estrus, the endometrial microenvironment plays an important role in successful embryo implantation and pregnancy maintenance.

Endometrial tissue is structured as a threedimensional (3D) microenvironment in vivo that consists of extracellular matrix (ECM) components and a number of distinct cell populations (Jokimaa et al. 2002, Yamada et al. 2002). The specificity of cells that constitute endometrial tissue at each stage of the estrus cycle is regulated by the alteration of $3 \mathrm{D}$ communication networks formed by the integration of cell-to-cell and cell-to-ECM contacts (Burghardt et al. 2002). To date, the endometrial microenvironment has been primarily constructed on two-dimensional culture plates rather than in 3D (Arnold et al. 2001), making it difficult to evaluate the effects of specific stimulations on endometrial tissue in vitro. Therefore, an in vitro mimic of the 3D endometrial microenvironment equivalent to endometrial tissue at each stage of the estrus cycle in vivo will be important for future studies.

The ECM, a non-cellular 3D macromolecular network composed of diverse fibrous ECM proteins, proteoglycans and glycoproteins (Kim et al. 2011, Theocharis et al. 2016) provides not only a physical scaffold to structure the 3D microenvironment but also signals a variety of cellular responses (Strauss 2013, Leppert et al. 2014). In particular, ECM-derived signals are transported to the cytoplasm through integrins that directly recognize components of the ECM (Rosso et al. 2004, Byron \& Frame 2016), resulting in cytological alterations (Gronthos et al. 2001, 
Vitillo et al. 2016). Therefore, the stimulation of ECM protein-derived signals through integrins makes it possible to accurately regulate the specificity of endometrial cells at each stage of the estrus cycle, which requires detailed information on the integrins that are functionally expressed on the membranes of cells that make up the endometrium.

As a step toward developing a defined non-cellular niche that uses integrin signaling to construct artificial and stereoscopic 3D endometrial tissues in mice, we examined the types of integrin heterodimers expressed on the membranes of ES and EE cells derived from the mouse uterus in estrus. Integrin subunits expressed in ES and EE cells were identified at the transcriptional and translational level, and the combinations of $\alpha$ and $\beta$ integrin subunits were determined with functional assays.

\section{Materials and methods}

\section{Animals}

Six- or seven-week-old female ICR mice in estrus identified through vaginal cytological evaluation described previously (McLean et al. 2012) were used as uterus endometrium cell donors. All animal housing, handling and experimental procedures were approved by the Institutional Animal Care and Use Committee (IACUC) of Kangwon National University (IACUC approval No. KW-150327-3) and conducted according to the Animal Care and Use Guidelines of Kangwon National University.

\section{Isolation of ES and EE cells from uterus}

Uterine horns washed with Hank's balanced salt solution (HBSS; Invitrogen) supplemented with $2 \%(\mathrm{v} / \mathrm{v})$ antibioticantimycotic solution (Welgene Inc., Daegu, Korea) were split longitudinally and the tissue fragmented into fine pieces by surgical scissors was digested using $1.5 \mathrm{mg} / \mathrm{mL}$ collagenase (Sigma-Aldrich) in HBSS at $37^{\circ} \mathrm{C}$ for $45 \mathrm{~min}$. Then, the digested cells were filtered through $100 \mu \mathrm{m}$ nylon mesh (SPL, Pocheon, Korea). A sedimentation step collected cell clumps in the tube bottom after separating the filtrated cells under unit gravity by incubating in a $15 \mathrm{~mL}$ tube at room temperature for $15 \mathrm{~min}$. This procedure was repeated three times to remove debris included in cell clump. Subsequently, an adherent step separated attached ES and suspended EE cells by incubating the cell clumps on a $100 \mathrm{~mm}$ culture plate at $37^{\circ} \mathrm{C}$ for $10 \mathrm{~min}$ that was repeated twice. Subsequently, two types of cells were isolated and counted using a hemocytometer.

\section{Real-time polymerase chain reaction}

According to the manufacturer's instructions, the Dynabeads mRNA Direct Kit (Ambion) was used for extracting total mRNA from the cells and cDNA was synthesized using the ReverTra Ace qPCR RT Master Mix with gDNA remover kit (Toyobo, Osaka, Japan). Then, the quantification of the specific gene expression was conducted using a THUNDERBIRD SYBR qPCR Mix (Toyobo) under the 7500 Real-time PCR system (Applied Biosystems), and melting curve date was analyzed for identifying PCR specificity. The mRNA level was presented as $2^{-\Delta C t}$, where

Table 1 Oligonucleotide primers and PCR cycling conditions.

\begin{tabular}{|c|c|c|c|c|c|}
\hline \multirow[b]{2}{*}{ Genes } & \multirow[b]{2}{*}{ GenBank number } & \multicolumn{2}{|c|}{ Primer sequence } & \multirow[b]{2}{*}{ Size (bp) } & \multirow[b]{2}{*}{ Temp $^{\mathrm{a}}$} \\
\hline & & Sense $\left(5^{\prime}>3^{\prime}\right)$ & Anti-sense $\left(5^{\prime}>3^{\prime}\right)$ & & \\
\hline Actb & X03672 & TACCACAGGCATTGTGATGG & TCTTTGATGTCACGCACGATT & 200 & 60 \\
\hline Itga 1 & NM_001033228 & TGGCCAACCCAAAGCAAGAA & AGGGCCCACATGCCAGAAAT & 200 & 60 \\
\hline Itga2 & NM_008396 & TGTGCACCCCCAGAGCACTT & TGTTCACTTGAAGGCCCGGA & 181 & 60 \\
\hline Itga3 & NM_013565 & AGCAACCTGCAGATGCGAGC & СТСАТGCGСАТСТТССССАG & 158 & 60 \\
\hline Itga4 & NM_010576 & AGCAAAAAGGCATAGCGGGG & AACGCTGGCTTCCTTCCCAC & 160 & 60 \\
\hline Itga5 & NM_010577 & AGGCTGCGCTGTGAGTTTGG & TGCCGAGGCAGGATCTGGTA & 178 & 60 \\
\hline Itga6 & X63251 & AGGTTCGAGTGACGGTGTTT & GTATCGGGGAATGCTGTCAT & 185 & 60 \\
\hline Itga7 & NM_008398 & GCTTCCCAGACATTGCCGTG & TCCATCCACATCCAGGCCAC & 182 & 60 \\
\hline Itga8 & NM_001001309 & GCATTCTTGACGTGGGCTGG & ATCСТСТGGGGAGGCAGCAG & 154 & 60 \\
\hline Itga9 & NM_133721 & GGGGCAGGTCACCGTCTACC & AGCCACATCTGGGAACCCGT & 156 & 60 \\
\hline Itga 10 & BC115770 & GCTGTCTCCATGCCACAGGC & GTGGGGAGGCATCACATCCA & 186 & 60 \\
\hline $\operatorname{ltga} 11$ & NM_176922 & TCCGGTAACCCAGGGCAACT & GCTTCCACACTCGTGCGACC & 172 & 60 \\
\hline Itgav & NM_008402 & AAGGCGCAGAATCAAGGGGA & CCAGCCTTCATCGGGTTTCC & 194 & 60 \\
\hline Itgal & NM_008400 & GGAAGCCTGGTGGGCTCAGT & AGCTCAGCACAACCACCCGA & 180 & 60 \\
\hline Itgam & NM_008401 & СTTTGCAATTGAGGGCACGC & GAAGGСТССАССТGСССАGT & 150 & 60 \\
\hline Itgad & NM_001029872 & TGTGGAGAAGCCCGTCGTGT & AGTGGCAGGCGCACAGTCAT & 157 & 60 \\
\hline Itgax & NM_021334 & GCTAGGGGACGTGAATGGGG & GGAGGGGATCTGGGATGCTG & 165 & 60 \\
\hline Itgae & NM_008399 & ACACAAGCCAAAGCССТТСТ & CAGGCTCTTGACTCTGGGTG & 186 & 60 \\
\hline Itgb 1 & NM_010578 & CTGGTCCCGACATCATCCCA & CCGTGTCCCACTTGGCATTC & 167 & 60 \\
\hline ltgb2 & NM_008404 & GGTGGCTCAGATCGGGGTTC & TGCACCTGTTGCATTGGCAG & 165 & 60 \\
\hline $\operatorname{ltg} 3$ & NM_016780 & ССССАССАСАGGСААТСААА & СССТCTGGGGCATCTCGATT & 166 & 60 \\
\hline $\operatorname{ltg} 44$ & ВС080751 & GGCCAGTGGCTCTCTCAGCA & GTGGTCAGCAAGCTCGTGGG & 151 & 60 \\
\hline ltgb5 & NM_010580 & AGGGCGTCСТATGСТCAGGC & AGACACAACGGCCTCGGTCA & 161 & 60 \\
\hline $\operatorname{ltg} b 6$ & NM_021359 & GTCCAAGGTGGCTGTGCCTG & TGCGGGAGACAGGGTTTTCA & 199 & 60 \\
\hline $\operatorname{ltg} b 7$ & NM_013566 & AAGGAGGGCTCTGCAGTGGG & TACAGTTGGCTGCCAGGGGA & 182 & 60 \\
\hline $\operatorname{ltg} b 8$ & BC125343 & GССТCAAGGTGCGСТСТCAA & AGGCTGCCCCAAGAACCAAG & 181 & 60 \\
\hline
\end{tabular}

a Temp, Temperature. 
$\mathrm{Ct}=$ threshold cycle for target amplification, $\Delta \mathrm{Ct}=\mathrm{Ct}_{\text {target gene }}$ (specific genes for each sample) $-\mathrm{Ct}_{\text {internal reference }}(\beta$-actin for each sample). Design of primer sequences by Primer3 software (Whitehead Institute/MIT Center for Genome Research) was performed with information of cDNA sequences obtained from GenBank for mouse, and Table 1 shows general information and sequences of primers.

\section{Immunocytochemistry}

The cells fixed with $4 \%(\mathrm{v} / \mathrm{v})$ paraformaldehyde (Junsei, Tokyo, Japan) for $10 \mathrm{~min}$ were washed with Dulbecco's phosphate-buffered saline (DPBS; Welgene), and the fixed cells were stained for $16 \mathrm{~h}$ at $4^{\circ} \mathrm{C}$ with fluorescenceconjugated anti-integrin antibodies diluted in DPBS. Table 2 describes the detailed information and dilution rate of the used antibodies. After rinsing with DPBS, the stained cells counterstained with mounting medium for fluorescence with DAPI (Vector Laboratories, Inc., Burlingame, CA, USA) were monitored under fluorescence microscope (BX53, Olympus).

\section{Fluorescence immunoassay}

The fixed cells were produced by incubating living cells in $4 \%(\mathrm{v} / \mathrm{v})$ paraformaldehyde for $10 \mathrm{~min}$. After washing twice with DPBS, they were stained for $2 \mathrm{~h}$ at room temperature with fluorescence-conjugated anti-integrin antibodies diluted in DPBS. Table 2 describes the detailed information and dilution rate of the used antibodies. Subsequently, the stained cells was washed with DPBS and fluorescence intensity was measured using SoftMax Pro 6.2.2. (Molecular Devices Cooperation, Sunnyvale, CA, USA) after adding $100 \mu \mathrm{L}$ DPBS to the stained cells.

\section{Attachment assay}

In order to prepare ECM substrate for cell adhesion, 96-well tissue culture plates were, respectively, coated with following concentrations of the purified ECM proteins: 0,5 and $10 \mu \mathrm{g} / \mathrm{mL}$ collagen I (Sigma-Aldrich) interacting with integrin $\alpha_{1} \beta_{1}, \alpha_{2} \beta_{1}$ (White et al. 2004, Znoyko et al. 2006, Heino 2007); 0, 40 and $80 \mu \mathrm{g} / \mathrm{mL}$ fibronectin (Millipore) interacting with integrin $\alpha_{3} \beta_{1}, \alpha_{4} \beta_{1}, \quad \alpha_{5} \beta_{1}$ and $\alpha_{8} \beta_{1}$ (Sanchez-Aparicio et al. 1994, Muller et al. 1995, Su et al. 2016, Veqa \& Schwarzbauer 2016); 0,200 and $400 \mu \mathrm{g} / \mathrm{mL}$ laminin (Sigma-Aldrich) interacting with integrin $\alpha_{3} \beta_{1}, \alpha_{6} \beta_{1}, \alpha_{6} \beta_{4}$ and $\alpha_{7} \beta_{1}$ (Kikkawa et al. 2000, Nishiuchi et al. 2006); 0,20 and $40 \mu \mathrm{g} / \mathrm{mL}$ tenascin C (R\&D systems) interacting with integrin $\alpha_{9} \beta_{1}$ (Yokosaki et al. 1994, Fiorilli et al. 2008); and 0,5 and $10 \mu \mathrm{g} / \mathrm{mL}$ vitronectin (R\&D Systems) interacting with integrin $\alpha_{v} \beta_{1}, \alpha_{v} \beta_{3}$ and $\alpha_{v} \beta_{5}$ (Bodary \& McLean 1990, Wayner et al. 1991, Delannet et al. 1994, Horton 1997) overnight at $4^{\circ} \mathrm{C}$. Subsequently, for inhibiting non-specific binding of cells, each well was blocked with $1 \%$ $(\mathrm{w} / \mathrm{v})$ bovine serum albumin (BSA; Sigma-Aldrich) at $4{ }^{\circ} \mathrm{C}$ for $1 \mathrm{~h}$ and washed three times with DPBS. Dulbecco's modified Eagle's medium: nutrient mixture F-12 (DMEM/F12; Invitrogen) supplemented with $10 \%(\mathrm{v} / \mathrm{v})$ heat-inactivated fetal bovine serum (FBS; Welgene) and 1\% (v/v) antibiotic-antimycotic solution was used as the culture medium to resuspend $5 \times 10^{4}$ cells. The resuspended cells were plated on to each well. After incubating at $37^{\circ} \mathrm{C}$ for $2 \mathrm{~h}$, the removal of non-adherent cells were conducted by washing sufficiently each well and adherent cells were fixed in $4 \%(\mathrm{v} / \mathrm{v})$ paraformaldehyde at room temperature for $10 \mathrm{~min}$. Then, the fixed adherent cells were stained with $0.1 \%(\mathrm{w} / \mathrm{v})$ crystal violet (Sigma-Aldrich) in $20 \%(\mathrm{v} / \mathrm{v})$ methanol (Sigma-Aldrich) for $5 \mathrm{~min}$. After washing twice with distilled water, the amount of adherent cells were quantified at $570 \mathrm{~nm}$ using a microplate reader (Epoch Microplate Spectrophotometer; BioTek Instruments Inc.,) after

Table 2 Antibodies used in experiments.

\begin{tabular}{|c|c|c|c|c|}
\hline Antibody name & Catalog number & Company & Application & Dilution rate \\
\hline FITC-conjugated American hamster anti-mouse integrin $\alpha_{2}$ & 103503 & BioLegend & $\begin{array}{l}\mathrm{Fl}^{\mathrm{a}} \\
\mathrm{ICC}^{\mathrm{C}}\end{array}$ & $\begin{array}{l}1: 100 \\
1: 50\end{array}$ \\
\hline FITC-conjugated rabbit anti-mouse integrin $\alpha_{5}$ & orb222105 & Biorbyt & $\mathrm{Fl}^{\mathrm{a}}$ & $1: 100$ \\
\hline PE-conjugated American hamster anti-mouse integrin $\alpha_{5}$ & $12-0493$ & eBioscience & $\mathrm{ICC}^{\mathrm{C}}$ & $1: 50$ \\
\hline Alexa Fluor488-conjugated rat anti-human/mouse integrin $\alpha_{6}$ & 313608 & BioLegend & $\begin{array}{l}\mathrm{FI}^{\mathrm{a}} \\
\mathrm{ICC}^{\mathrm{c}}\end{array}$ & $\begin{array}{l}1: 100 \\
1: 50\end{array}$ \\
\hline FITC-conjugated mouse anti-mouse integrin $\alpha_{7}$ & LS-C179570 & LSBio & $\begin{array}{l}\mathrm{Fl}^{\mathrm{a}} \\
\mathrm{ICC}^{\mathrm{c}}\end{array}$ & $\begin{array}{l}1: 100 \\
1: 50\end{array}$ \\
\hline FITC-conjugated rabbit anti-mouse integrin $\alpha_{9}$ & orb188618 & Biorbyt & $\mathrm{Fl}^{\mathrm{a}}$ & $1: 100$ \\
\hline PE-conjugated goat anti-mouse integrin $\alpha_{9}$ & FAB3827P & R\&D Systems & $\mathrm{ICC}^{\mathrm{C}}$ & $1: 50$ \\
\hline FITC-conjugated rabbit anti-mouse integrin $\alpha_{V}$ & orb7231 & Biorbyt & $\begin{array}{l}\mathrm{Fl}^{\mathrm{a}} \\
\mathrm{ICC}^{\mathrm{c}}\end{array}$ & $\begin{array}{l}1: 100 \\
1: 50\end{array}$ \\
\hline FITC-conjugated rat anti-mouse integrin $\beta_{1}$ & FAB2405F & R\&D Systems & $\begin{array}{l}\mathrm{Fl}^{\mathrm{a}} \\
\mathrm{ICC}^{\mathrm{c}}\end{array}$ & $\begin{array}{l}1: 100 \\
1: 50\end{array}$ \\
\hline FITC-conjugated American hamster anti-mouse integrin $\beta_{3}$ & 104305 & BioLegend & $\begin{array}{l}\mathrm{Fl}^{\mathrm{a}} \\
\mathrm{ICC}^{\mathrm{c}}\end{array}$ & $\begin{array}{l}1: 100 \\
1: 50\end{array}$ \\
\hline FITC-conjugated rat anti-mouse integrin $\beta_{4}$ & FAB4054F & R\&D Systems & $\begin{array}{l}\mathrm{Fl}^{\mathrm{a}} \\
\mathrm{ICC}^{\mathrm{c}}\end{array}$ & $\begin{array}{l}1: 100 \\
1: 50\end{array}$ \\
\hline FITC-conjugated mouse anti-mouse integrin $\beta_{5}$ & $11-0497$ & eBioscience & $\begin{array}{l}\mathrm{Fl}^{\mathrm{a}} \\
\mathrm{ICC}^{\mathrm{c}}\end{array}$ & $\begin{array}{l}1: 100 \\
1: 50\end{array}$ \\
\hline $\begin{array}{l}\text { LEAF purified American hamster anti-mouse integrin } \alpha_{2} \\
\text { LEAF purified rat anti-mouse integrin } \alpha_{5} \\
\text { Rat anti-mouse integrin } \alpha_{6} \\
\text { LEAF purified rat anti-mouse integrin } \alpha_{V}\end{array}$ & $\begin{array}{l}103507 \\
103807 \\
\text { MAB } 1378 \\
104107\end{array}$ & $\begin{array}{l}\text { BioLegend } \\
\text { BioLegend } \\
\text { Millipore } \\
\text { BioLegend }\end{array}$ & $\begin{array}{l}A I A^{b} \\
A^{b} A^{b} \\
A^{b} A^{b} \\
A^{b} A^{b}\end{array}$ & $\begin{array}{l}1: 10 \\
1: 10 \\
1: 10 \\
1: 10\end{array}$ \\
\hline
\end{tabular}

${ }^{a} \mathrm{FI}$, fluorescence immunoassay, ${ }^{\mathrm{b}} \mathrm{AIA}$, antibody inhibition assay, ${ }^{\mathrm{I} I C C}$, immunocytochemisty. 
adding $50 \mu \mathrm{L}$ of $0.2 \%$ (v/v) triton X-100 (Biopure, Cambridge, MA, USA) diluted with distilled water.

\section{Antibody inhibition assay}

Each well of 96-well tissue culture plate was coated with $5 \mu \mathrm{g} / \mathrm{mL}$ collagen I, $40 \mu \mathrm{g} / \mathrm{mL}$ fibronectin, $200 \mu \mathrm{g} / \mathrm{mL}$ laminin or $5 \mu \mathrm{g} / \mathrm{mL}$ vitronectin overnight at $4^{\circ} \mathrm{C}$, and the coated wells was blocked with $1 \%(\mathrm{w} / \mathrm{v}) \mathrm{BSA}$ for $1 \mathrm{~h}$ at $4^{\circ} \mathrm{C}$. Subsequently, function of integrins was inhibited by incubating $5 \times 10^{4}$ cells in DMEM/F12 culture medium including anti-integrin $\alpha_{2}(\mathrm{HM} \alpha 2)$, anti-integrin $\alpha_{5}(5 \mathrm{H} 10-27$ (MFR5)), anti-integrin $\alpha_{6}$ (NKI-GoH3) or anti-integrin $\alpha_{V}$ (RMV-7) blocking antibody for $2 \mathrm{~h}$ at $37^{\circ} \mathrm{C}$, and the detailed information regarding the used antibodies is described in Table 2. Next, the functionally blocked cells was plated on the each well and incubated at $37^{\circ} \mathrm{C}$ for $8 \mathrm{~h}$. The non-adherent cells were removed by washing extensively with DPBS, the adherent cells were fixed in $4 \%(\mathrm{v} / \mathrm{v})$ paraformaldehyde for $10 \mathrm{~min}$ at room temperature and the fixed adherent cells was stained with $0.1 \%(\mathrm{w} / \mathrm{v})$ crystal violet in $20 \%(\mathrm{v} / \mathrm{v})$ methanol for $5 \mathrm{~min}$. Finally, the wells washed twice with distilled water were supplemented with $50 \mu \mathrm{L} 0.2 \%(\mathrm{v} / \mathrm{v})$ triton $\mathrm{X}-100$ diluted with distilled water and the amount of dye was measured at $570 \mathrm{~nm}$ using a microplate reader.

\section{Statistical analysis}

The Statistical Analysis System (SAS) program was used for analyzing statistically all the numerical data shown in each experiment. Comparison among treatment groups were performed by the least-square or DUNCAN method, when significance of the main effects through variance (ANOVA) analysis was detected in the SAS package. Moreover, significant differences among treatments were determined when $P$ value was less than 0.05 .

\section{Results}

\section{Characterization of the integrin subunits expressed on the membranes of ES and EE cells derived from the mouse uterine endometrium in estrus}

To determine the types of integrin heterodimers expressed on the membranes of ES and EE cells in the uterine endometrium in estrus, we investigated the

B
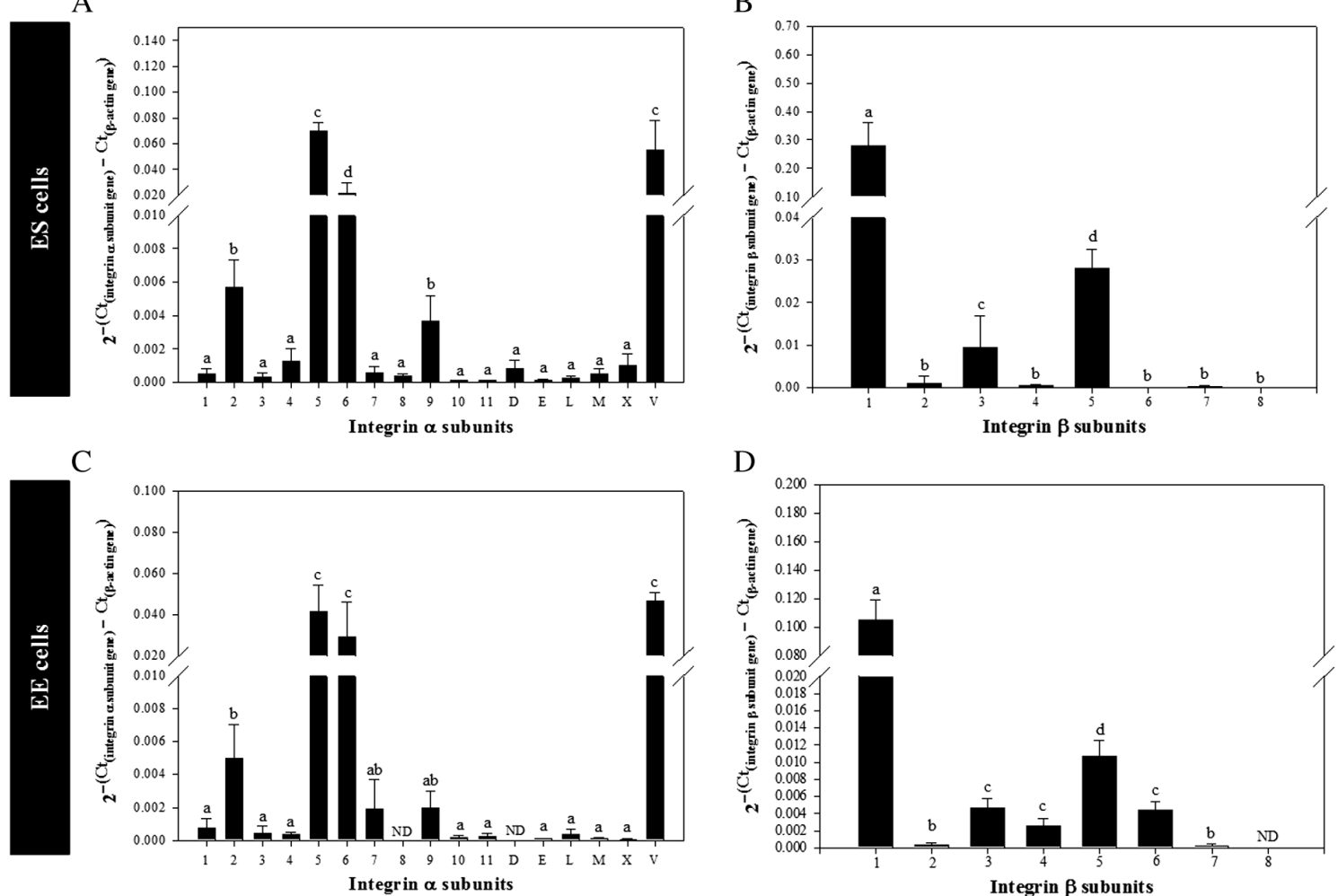

$\mathrm{D}$

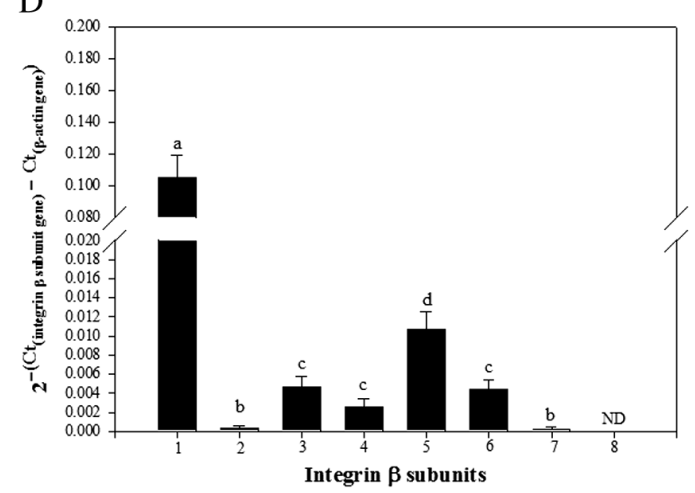

Figure 1 Transcriptional levels of $\alpha$ and $\beta$ integrin subunit genes in endometrial stromal (ES) and endometrial epithelial (EE) cells of mouse uterine tissue. Endometrial cells were retrieved enzymatically from uterus derived from imprinting control region (ICR) mice, and the isolation of ES and EE cells was conducted using a sedimentation-adherence method. mRNA levels of $\alpha$ and $\beta$ integrin subunit genes in the isolated ES or EE cells were quantitatively monitored by real-time PCR. Among the total $17 \alpha$ and $8 \beta$ integrin subunit genes, $5 \alpha\left(\alpha_{2}, \alpha_{5}, \alpha_{6}, \alpha_{9}\right.$, and $\left.\alpha_{V}\right)$ (A) and $3 \beta$ $\left(\beta_{1}, \beta_{3}\right.$, and $\left.\beta_{5}\right)$ (B) subunits in ES cells, and $4 \alpha\left(\alpha_{2}, \alpha_{5}, \alpha_{6}\right.$ and $\left.\alpha_{v}\right)(C)$ and $5 \beta\left(\beta_{1}, \beta_{3}, \beta_{4}, \beta_{5}\right.$, and $\left.\beta_{6}\right)$ (D) subunits in EE cells showed significantly increased transcription compared with the other integrin subunit genes. Moreover, $2 \alpha\left(\alpha_{7}\right.$ and $\left.\alpha_{9}\right)$ subunits in EE cells showed stronger transcription than $9 \alpha\left(\alpha_{1}, \alpha_{3}, \alpha_{4}, \alpha_{10}, \alpha_{11}, \alpha_{E^{\prime}}, \alpha_{L}, \alpha_{M}\right.$ and $\left.\alpha_{X}\right)$ subunits showing the minimum transcription, with no significant difference in the transcriptional level from integrin $\alpha_{2}$ subunit (C). All data shown are mean \pm standard deviation (s.D.) of three independent experiments.

${ }^{\mathrm{a}-\mathrm{d}} P<0.05 . \mathrm{ND}=$ not detected. 
transcriptional and translational expression of integrin subunits. Transcriptional analysis of the genes encoding $17 \alpha$ and $8 \beta$ integrin subunits revealed that ES cells showed significantly higher expression of integrin $\alpha_{2}$, $\alpha_{5}, \alpha_{6}, \alpha_{9}$ and $\alpha_{V}$ (Fig. 1A), and integrin $\beta_{1}, \beta_{3}$ and $\beta_{5}$ (Fig. 1B) subunit genes. EE cells showed significantly higher expression of integrin $\alpha_{2}, \alpha_{5}, \alpha_{6}$ and $\alpha_{V}$ (Fig. 1C), and integrin $\beta_{1}, \beta_{3}, \beta_{4}, \beta_{5}$ and $\beta_{6}$ (Fig. 1D) subunit genes. The minimum level of expression was detected for the integrin subunit genes $\alpha_{1}, \alpha_{3}, \alpha_{4}, \alpha_{7}, \alpha_{8}, \alpha_{10}, \alpha_{11}, \alpha_{D}, \alpha_{E}$ $\alpha_{\mathrm{L}}, \alpha_{\mathrm{M}}$ and $\alpha_{\mathrm{X}}$ (Fig. 1A), and $\beta_{2}, \beta_{4}, \beta_{6}, \beta_{7}$ and $\beta_{8}$ (Fig. 1B) in ES cells, and for $\alpha_{1}, \alpha_{3}, \alpha_{4}, \alpha_{7}, \alpha_{9}, \alpha_{10}, \alpha_{11}, \alpha_{E}, \alpha_{L}, \alpha_{M}$ and $\alpha_{x}$ (Fig. 1C), and $\beta_{2}$ and $\beta_{7}$ (Fig. 1D) in EE cells. Moreover, in EE cells, the expression of the integrin $\alpha_{7}$ and $\alpha_{9}$ subunit genes with no significant difference from integrin $\alpha_{2}$ subunit gene was higher than the other integrin subunit genes with minimum expression (Fig. 1C). No transcription of the subunits $\alpha_{8}, \alpha_{D}$ (Fig. 1C) or $\beta_{8}$ (Fig. 1D) was detected in EE cells.

We also examined translational regulation of the $\alpha$ and $\beta$ integrin subunits that showed increased transcription. In ES cells, the expression of integrin $\alpha_{2}, \alpha_{5}, \alpha_{6}, \alpha_{9}, \alpha_{V}, \beta_{1}$, $\beta_{3}$ and $\beta_{5}$ subunit proteins was observed on the surface of cells (Fig. 2A, B, C, D, E, F, G and H), and the integrin subunit proteins $\alpha_{5}$ (Fig. 3A) and $\beta_{3}$ (Fig. 3B) had the strongest expression among the five $\alpha\left(\alpha_{2}, \alpha_{5}, \alpha_{6}, \alpha_{9}\right.$ and $\left.\alpha_{v}\right)$ and three $\beta\left(\beta_{1}, \beta_{3}\right.$ and $\left.\beta_{5}\right)$ integrin subunits. In addition, among the $\alpha\left(\alpha_{2}, \alpha_{6}, \alpha_{9}\right.$ and $\left.\alpha_{v}\right)$ and $\beta\left(\beta_{1}\right.$ and $\beta_{5}$ ) subunits with significantly weaker expression than $\alpha_{5}$ and $\beta_{3}$, significantly stronger expression was detected in integrin $\alpha_{9}$ and $\alpha_{V}$ subunit proteins (Fig. 3A) compared with $\alpha_{2}$ and $\alpha_{6}$, and no significant difference in the expression of $\beta_{1}$ and $\beta_{5}$ subunits was observed (Fig. 3B). In EE cells, the localization of integrin $\alpha_{2}, \alpha_{5}, \alpha_{6}, \alpha_{7}, \alpha_{9}$, $\alpha_{V}, \beta_{1}, \beta_{3} \beta_{4}$ and $\beta_{5}$ subunit proteins was identified on the surface of cells (Fig. 2I, J, K, L, M, N, O, P, Q and R). The strongest expression among the six $\alpha\left(\alpha_{2}, \alpha_{5}, \alpha_{6}, \alpha_{7}, \alpha_{9 \prime}\right.$ and $\left.\alpha_{v}\right)$ and four $\beta\left(\beta_{1}, \beta_{3}, \beta_{4}\right.$, and $\left.\beta_{5}\right)$ integrin subunits was detected for $\alpha_{5}$ (Fig. 3C) and $\beta_{3}$ (Fig. 3D), whereas significantly lower expression was observed for the other integrin $\alpha\left(\alpha_{2}, \alpha_{6}, \alpha_{7}, \alpha_{9}\right.$, and $\left.\alpha_{V}\right)$ and $\beta\left(\beta_{1}, \beta_{4}\right.$, and $\left.\beta_{5}\right)$ subunits. The expression of $\alpha$ integrin subunits did not show any significant differences among the $\alpha_{2}, \alpha_{6}, \alpha_{7}$, $\alpha_{9}$ and $\alpha_{V}$ subunits (Fig. 3 C), and the integrin $\beta_{1}$ subunit
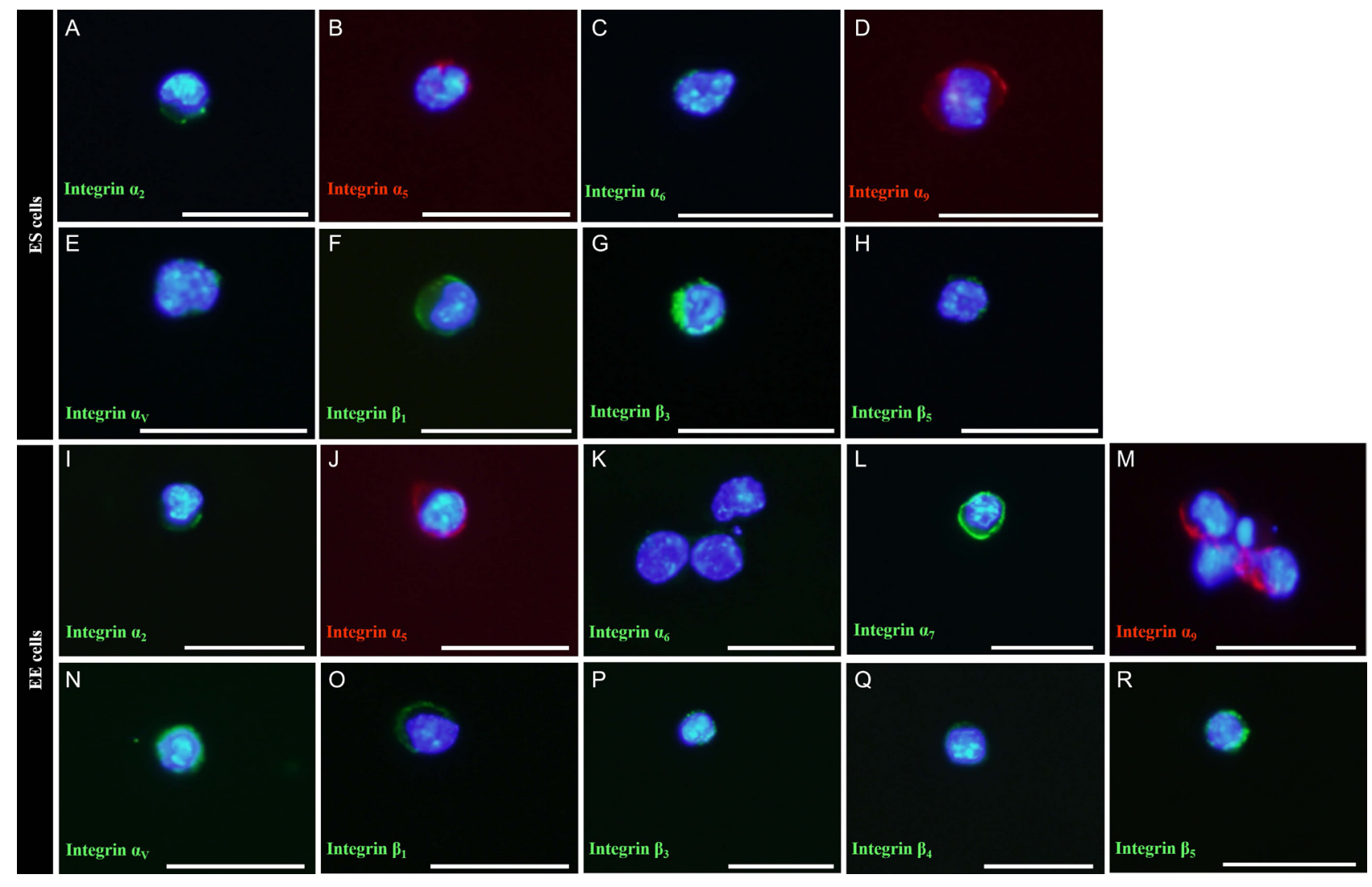

Figure 2 Translational expression of $\alpha$ and $\beta$ integrin subunit genes highly expressed in ES and EE cells of mouse uterine tissue. Using a sedimentation-adherence method, ES and EE cells were isolated from endometrial cells retrieved enzymatically from uterus derived from ICR mice. Translational expression of $\alpha$ and $\beta$ integrin subunit genes in the sorted ES and EE cells were identified by immunocytochemistry. As a result, integrin $\alpha_{2}, \alpha_{5}, \alpha_{6}, \alpha_{9}, \alpha_{V}, \beta_{1}, \beta_{3}$ and $\beta_{5}$ subunit proteins (A, B, C, D, E, F, G and H) were localized on the surface of ES cells, and the surface of EE cells showed the expression of integrin $\alpha_{2}, \alpha_{5}, \alpha_{6}, \alpha_{7}, \alpha_{9}, \alpha_{V}, \beta_{1}, \beta_{3}, \beta_{4}$ and $\beta_{5}$ subunit proteins (I, J, K, L, M, N, O, P, Q and R). All figures are representative immunocytochemistry images of integrin subunit proteins expressed on the surface of ES and EE cells, respectively. $n=3$. Scale bars represent $20 \mu \mathrm{m}$. 
A
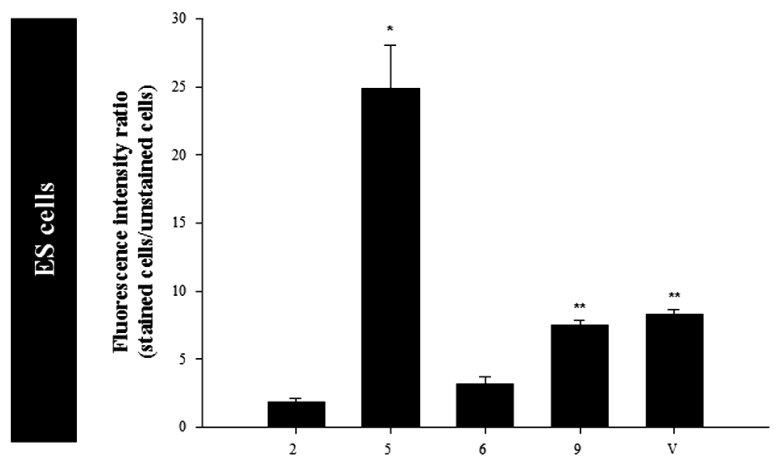

Integrin $\alpha$ subunits

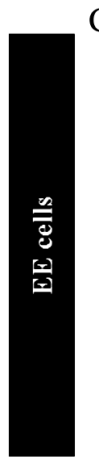

C

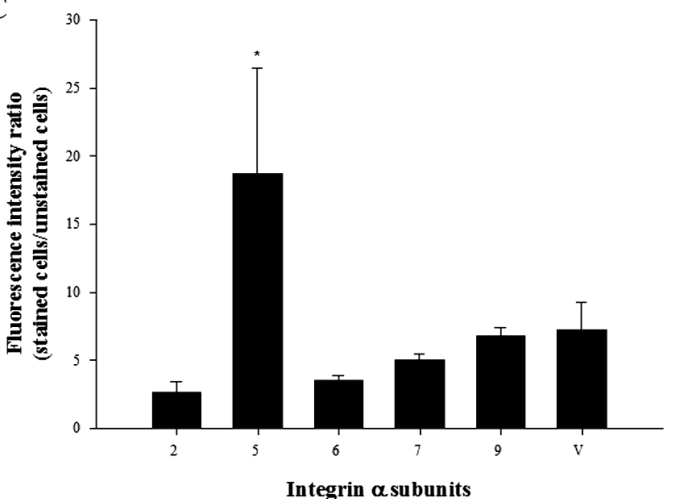

B

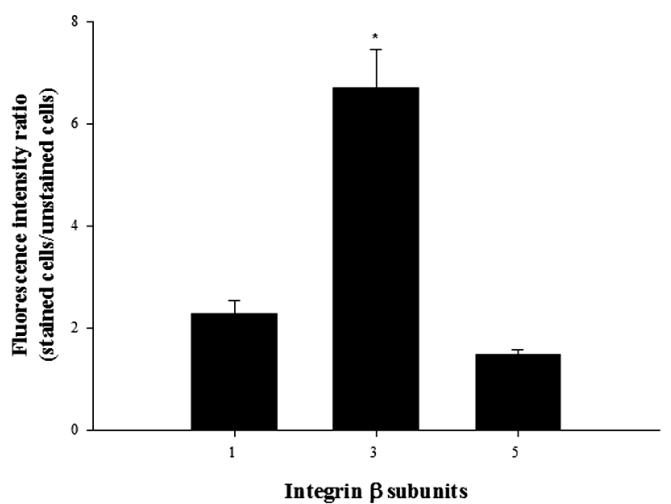

D

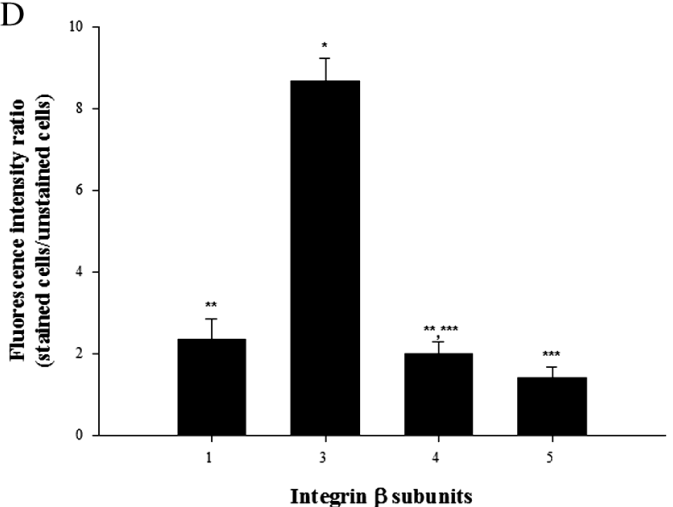

Figure 3 Translational levels of $\alpha$ and $\beta$ integrin subunit genes highly expressed in ES and EE cells of mouse uterine tissue. Using a sedimentation-adherence method, ES and EE cells were isolated from endometrial cells retrieved enzymatically from uterus derived from ICR mice. Translational levels of $\alpha$ and $\beta$ integrin subunit genes in the sorted ES and EE cells were quantified by fluorescence immunoassays. Among the total of five $\alpha$ and three $\beta$ integrin subunits in ES cells, significantly strong expression of three $\alpha\left(\alpha_{5}, \alpha_{9}\right.$ and $\left.\alpha_{V}\right)(A)$ and $\beta_{3}$ (B) subunits was detected, whereas two $\alpha\left(\alpha_{2}\right.$ and $\left.\alpha_{6}\right)$ (A) and two $\beta\left(\beta_{1}\right.$ and $\beta_{5}$ ) (B) subunits were weakly expressed. Among the total of six $\alpha$ and four $\beta$ integrin subunits in EE cells, $\alpha_{5}$ and $\beta_{3}$ subunits were strongly expressed, whereas significantly weak expression of five $\alpha\left(\alpha_{2}, \alpha_{6}, \alpha_{7}, \alpha_{9}\right.$ and $\left.\alpha_{V}\right)(C)$ and three $\beta\left(\beta_{1}, \beta_{4}\right.$ and $\left.\beta_{5}\right)$ (D) subunits was detected. All data shown are mean \pm s.D. of three independent experiments. ${ }^{*}, * * P<0.05$.

showed the highest significant expression among the $\beta_{1}$ $\beta_{4}$ and $\beta_{5}$ subunits (Fig. 3D). These results indicate that ES cells present $\alpha_{2}, \alpha_{5}, \alpha_{6}, \alpha_{9}$ and $\alpha_{V}$, and $\beta_{1}, \beta_{3}$ and $\beta_{5}$ integrin subunits, and EE cells present $\alpha_{2}, \alpha_{5}, \alpha_{6}, \alpha_{7}, \alpha_{9}$ and $\alpha_{V}$, and $\beta_{1}, \beta_{3}, \beta_{4}$ and $\beta_{5}$ integrin subunits on the cell surface.

\section{Functional identification of integrin heterodimers expressed on the membranes of ES and EE cells derived from mouse uterine endometrium in estrus}

Based on the identification of the $\alpha$ and $\beta$ integrin subunits expressed on the membranes of ES and EE cells derived from mouse uterine endometrium in estrus, we surmised that ES cells possess $\alpha_{2} \beta_{1}, \alpha_{5} \beta_{1}, \alpha_{6} \beta_{1}, \alpha_{9} \beta_{1}$, $\alpha_{v} \beta_{1}, \alpha_{v} \beta_{3}$ and $\alpha_{v} \beta_{5}$, and EE cells possess $\alpha_{2} \beta_{1}, \alpha_{5} \beta_{1}, \alpha_{6} \beta_{1}$, $\alpha_{6} \beta_{4}, \alpha_{7} \beta_{1}, \alpha_{9} \beta_{1}, \alpha_{v} \beta_{1}, \alpha_{v} \beta_{3}$ and $\alpha_{v} \beta_{5}$ as active forms of integrin heterodimers, as described previously (Lessey 1988, Reddy \& Mangale 2003). The presence of these integrin heterodimers was investigated by estimating levels of adherent ES and EE cells cultured on purified ECM proteins that interact specifically with each integrin heterodimer. Post-culture adherent levels of ES and EE cells treated with antibodies specifically blocking the function of each integrin were determined.

Compared with purified ECM protein-free culture plates, ES cells showed significantly improved adhesion to collagen I- (Fig. 4A), fibronectin- (Fig. 4B) and vitronectin-coated (Fig. 4E) culture plates, and EE cells to collagen I- (Fig. 4F), fibronectin- (Fig. 4G), laminin(Fig. $4 \mathrm{H}$ ) and vitronectin-coated (Fig. 4J) culture plates. Moreover, no significant differences in adhesion levels were observed in ES cells cultured on laminin- (Fig. 4C) or EE cells cultured on tenascin C-coated (Fig. 4l) culture plates. Rather, ES cells cultured on tenascin C-coated culture plates showed a significant decrease in the level of adhesion, compared to those cultured on purified ECM protein-free culture plates (Fig. 4D). These results suggest the presence of the collagen I-specific integrin $\alpha_{2} \beta_{1}$, fibronectin-specific integrin $\alpha_{5} \beta_{1}$ and vitronectinspecific integrin $\alpha_{v} \beta_{1}, \alpha_{v} \beta_{3}$ or $\alpha_{v} \beta_{5}$ on the cell membrane of mouse ES cells, with the presence of individual integrin subunits $\alpha_{6}$ and $\alpha_{9}$. Simultaneously, we speculate the presence of the collagen I-specific integrin 

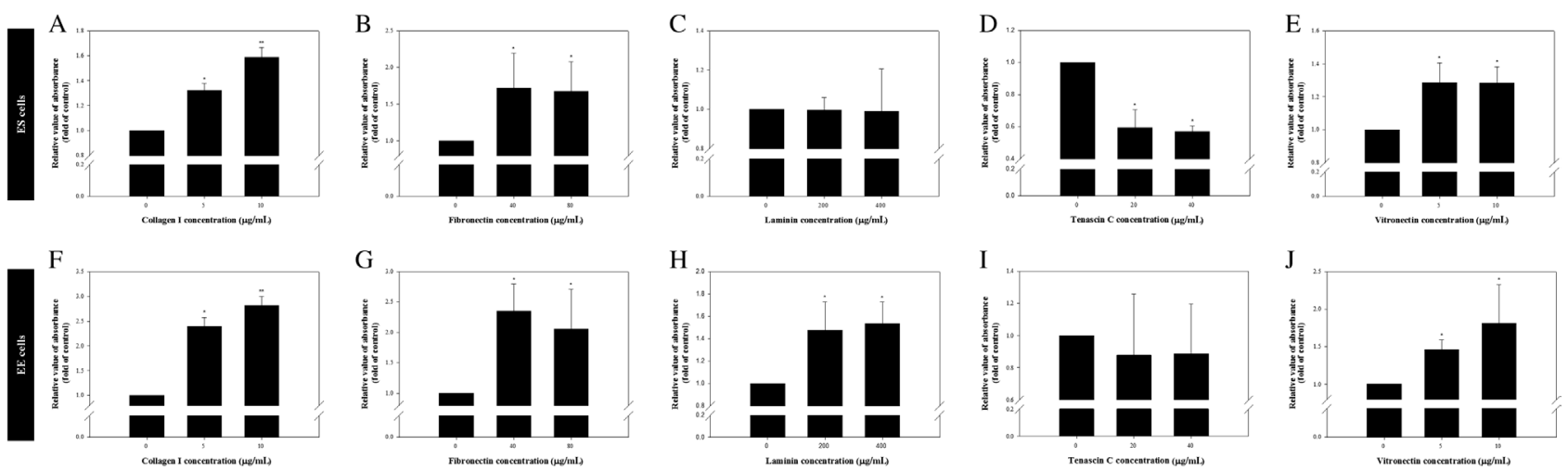

Figure 4 Identification of integrin heterodimers that interact with fibronectin, laminin and vitronectin on the membrane of ES and EE cells derived from the mouse uterus. A 96-well tissue culture plate was coated with collagen I, fibronectin, laminin, tenascin C, vitronectin, and ES or EE cells resuspended in culture medium were plated in each well. Subsequently, adherent cells were stained with crystal violet, and the level of adhesion was quantified using a microplate reader. The percentage of maximum adhesion is represented as the optical density of cells plated on extracellular matrix (ECM) protein-free plates. Both mouse ES and EE cells cultured on collagen I- (A, F), fibronectin- (B, G) and vitronectincoated $(E, J)$ culture plates showed significantly higher levels of adhesion than those on ECM protein-free culture plates. However, no significant difference or significant decrease in adhesion level was detected in ES cells cultured on laminin- (C) and tenascin C-coated (D) culture plates, respectively. In addition, EE cells cultured on laminin- $(\mathrm{H})$ or tenascin C-coated (I) culture plates showed significant improvement, or no significant difference, in adhesion levels compared to those on ECM protein-free culture plates. All data shown are mean \pm S.D. of three independent experiments. ${ }^{*}{ }^{* *} P<0.05$.

$\alpha_{2} \beta_{1}$; fibronectin-specific integrin $\alpha_{5} \beta_{1}$; laminin-specific integrins $\alpha_{6} \beta_{1}, \alpha_{6} \beta_{4}$ and/or $\alpha_{7} \beta_{1}$; and vitronectin-specific integrins $\alpha_{v} \beta_{1}, \alpha_{v} \beta_{3}$ and/or $\alpha_{v} \beta_{5}$ on the cell membrane of mouse EE cells, with the presence of the individual integrin subunit $\alpha_{9}$.

These specific integrin function-blocked mouse ES or EE cells were incubated on $5 \mu \mathrm{g} / \mathrm{mL}$ collagen I, $40 \mu \mathrm{g} / \mathrm{mL}$ fibronectin, $200 \mu \mathrm{g} / \mathrm{mL}$ laminin or $5 \mu \mathrm{g} / \mathrm{mL}$ vitronectin as the minimum concentration among those seen in
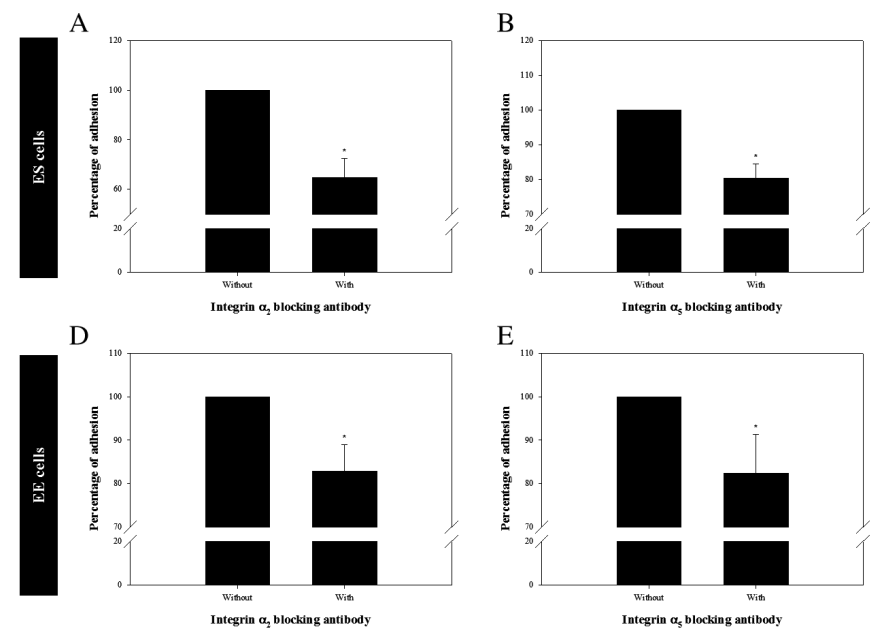

the ECM showing significantly improved adhesion of ES or EE cells (Fig. 5). Significantly lower adhesion was detected in ES cells with blockage of the integrin subunit $\alpha_{2}$ (Fig. 5A), $\alpha_{5}$ (Fig. 5B) or $\alpha_{V}$ (Fig. 5C), and in EE cells with blockage of the integrin subunit $\alpha_{2}$ (Fig. 5D), $\alpha_{5}$ (Fig. 5E), $\alpha_{6}$ (Fig. 5F) or $\alpha_{V}$ (Fig. 5G), compared with cells without blockage of those integrin heterodimers. From these results, we could confirm that the mouse endometrial ES cells derived from the uterus in estrus
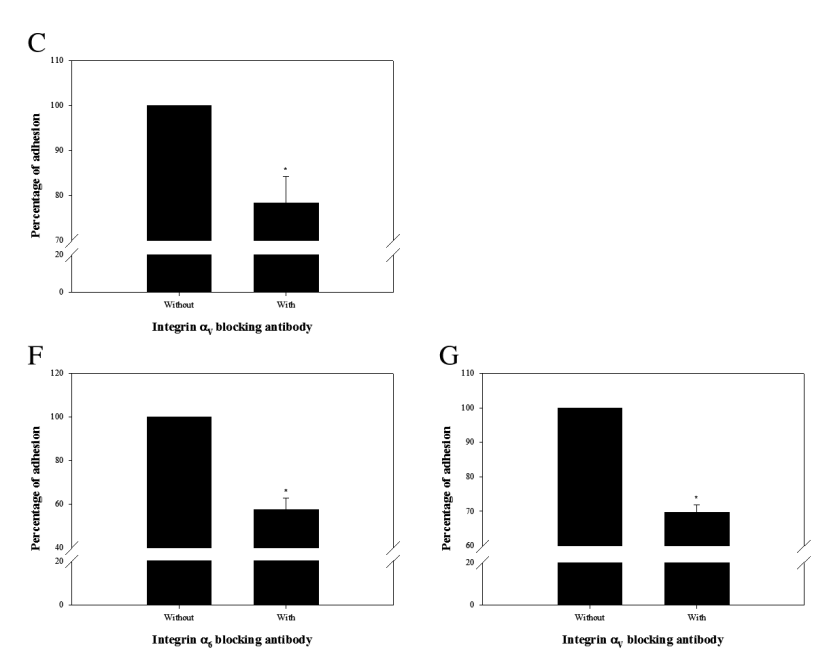

Figure 5 Functional analysis of integrin heterodimers on the membrane of ES and EE cells derived from the mouse uterus. Mouse ES and EE cells incubated in the absence or presence of anti-integrin $\alpha_{2}$, anti-integrin $\alpha_{5}$, anti-integrin $\alpha_{6}$ or anti-integrin $\alpha_{v}$ blocking antibodies were plated on $5 \mu \mathrm{g} / \mathrm{mL}$ collagen I-, $40 \mu \mathrm{g} / \mathrm{mL}$ fibronectin-, $200 \mu \mathrm{g} / \mathrm{mL}$ laminin- and $5 \mu \mathrm{g} / \mathrm{mL}$ vitronectin-coated wells, and incubated for $2 \mathrm{~h}$ at $37^{\circ} \mathrm{C}$. After staining adherent cells with crystal violet, the level of adherence was quantified using a microplate reader. As the parameter of functional blocking by antibodies, the percentage of maximum adhesion, represented by the optical density of cells plated on each ECM protein-coated well in the absence of blocking antibodies was determined. Mouse ES cells treated with integrin $\alpha_{2}(A), \alpha_{5}$ (B) and $\alpha_{V}(C)$ subunit blocking antibodies showed significantly lower rates of attachment to collagen I, fibronectin and vitronectin compared with those without blocking antibodies, respectively. Moreover, compared with those not treated with blocking antibodies, functional blocking of integrin $\alpha_{2}(\mathrm{D}), \alpha_{5}(\mathrm{E}), \alpha_{6}(\mathrm{~F})$ and $\alpha_{V}(G)$ subunits in EE cells significantly decreased the rates of attachment to collagen I, fibronectin, laminin and vitronectin, respectively. All data shown are mean \pm S.D. of three independent experiments. $* P<0.05$. 
simultaneously express the functional integrins $\alpha_{2} \beta_{1}$, $\alpha_{5} \beta_{1}, \alpha_{v} \beta_{1}, \alpha_{v} \beta_{3}$ and/or $\alpha_{v} \beta_{5}$ on the cell membrane, and integrins $\alpha_{2} \beta_{1}, \alpha_{5} \beta_{1}, \alpha_{6} \beta_{1}$ and/or $\alpha_{6} \beta_{4}$, and $\alpha_{v} \beta_{1}$, $\alpha_{v} \beta_{3}$ and/or $\alpha_{v} \beta_{5}$ on the membrane of mouse uterine endometrial EE cells.

\section{Discussion}

Knowledge of the ECM-derived signals that mediate intracytoplasmic transduction through cell surface receptors that belong to the integrin family will be essential in the construction of an artificial microenvironment that accurately reflects the in vitro organization of the endometrium, including in terms of ES and EE cells. Identification of the integrins expressed in ES and EE cells will be particularly important. Here, we report the types of integrin heterodimers expressed on the surface of ES and EE cells derived from the mouse endometrium during estrus. Transcriptional analysis of $17 \alpha$ and $8 \beta$ integrin subunits, followed by confirmation of their expression at the translational level, attachment to ECM proteins and inhibition with blocking antibodies revealed the presence of integrin $\alpha_{2} \beta_{1}, \alpha_{5} \beta_{1}, \alpha_{v} \beta_{1}, \alpha_{v} \beta_{3}$ and/or $\alpha_{v} \beta_{5}$ as heterodimers, and $\alpha_{6}$ and $\alpha_{9}$ as individual subunits on the ES cell membrane. EE cells expressed the integrin heterodimers $\alpha_{2} \beta_{1}, \alpha_{5} \beta_{1}, \alpha_{6} \beta_{1}$ and/or $\alpha_{6} \beta_{4}$, and $\alpha_{v} \beta_{1}, \alpha_{v} \beta_{3}$ and/or $\alpha_{\vee} \beta_{5}$, and the individual subunits $\alpha_{7}$ and $\alpha_{9}$ on the cell membrane. These results suggest that the collagen I-specific integrin $\alpha_{2} \beta_{1}$, fibronectinspecific integrin $\alpha_{5} \beta_{1}$ and vitronectin-specific integrins $\alpha_{v} \beta_{1}, \alpha_{v} \beta_{3}$ or $\alpha_{v} \beta_{5}$ in ES cells, and the collagen I-specific integrin $\alpha_{2} \beta_{1}$, fibronectin-specific integrin $\alpha_{5} \beta_{1}$, laminin-specific integrins $\alpha_{6} \beta_{1}$ or $\alpha_{6} \beta_{4}$ and vitronectinspecific integrins $\alpha_{v} \beta_{1}, \alpha_{v} \beta_{3}$ or $\alpha_{v} \beta_{5}$ in EE cells may be important for the transmission of extracellular signals that organize endometrial tissue. Moreover, collagen I, fibronectin, laminin and vitronectin analogs will be important for the construction of niches customized to the organization of endometrial tissue. In addition, we speculate that the integrin subunits $\alpha_{6}$ and $\alpha_{9}$ in ES cells, or $\alpha_{7}$ and $\alpha_{9}$ in EE cells, may play an important role in the cytological changes of ES or EE cells generated during the estrus cycle.

Generally, functional integrins are organized as heterodimers of $\alpha$ and $\beta$ subunits (Multhaupt et al. 2016, Pan et al. 2016). These heterodimeric transmembrane receptors are activated by direct interaction with a binding motif embedded in ECM proteins (Brizzi et al. 2012, Seguin et al. 2015) and they induce a variety of biological responses (Hynes 2009, Schaefer \& Reinhardt 2016). Therefore, despite the transcriptional and translational expression of the $\alpha_{6}$ and $\alpha_{9}$ integrin subunit genes in ES cells (Figs 1,2 and 3), the lack of a significant increase in the adhesion of ES cells to laminin (Fig. 4C) or tenascin C (Fig. 4D) was observed. These results indicate that $\alpha_{6}$ or $\alpha_{9}$ are localized in the inactive form as an individual subunit, and not as the active heterodimer, on the surface of the cell membrane. Furthermore, EE cells with the $\alpha_{6}$ and $\alpha_{7}$ subunits that recognize laminin exhibited a significant decrease in adhesion resulting from blockade of the $\alpha_{6}$ subunit (Fig. 5F), indicating that $\alpha_{6}$ is present as a heterodimer and $\alpha_{7}$ as an individual subunit. There was also no significant difference in the adhesion level of EE cells to tenascin C (Fig. 4I), indicating that $\alpha_{9}$ is present as an individual subunit on the cell membrane. These results are strongly supported by previous studies reporting the absence of laminin in ES tissue (Faber et al. 1986) and tenascin C in both ES (Julian et al. 1994, Michie \& Head 1994) and EE tissue (Michie \& Head 1994).

Interestingly, integrins $\alpha_{6} \beta_{1}$ and $\alpha_{6} \beta_{4}$, heterodimers that interact specifically with laminin were only observed on the surface of EE cells in estrus, and $\alpha_{6}$, identified as an individual subunit in the inactive form, are localized on the membrane of ES cells in estrus. This suggests that laminin-specific integrin heterodimers may play an important role in endometrial receptivity for implantation, which is supported by reports on the expression of laminin in the trophectoderm (Klaffky et al. 2006) and failed pregnancy in the laminin-deficient mouse (Zhang et al. 2000). Furthermore, the expression of laminin-specific integrin heterodimers in mouse EE cells has also been shown in humans (Koks et al. 2000, Park et al. 2000). Accordingly, at the clinical level, the presence of functional integrin heterodimers with the $\alpha_{6}$ subunit may be important for the diagnosis of healthy uterine epithelium.

The uterine endometrium experiences physical and physiological alterations during implantation (Kao et al. 2002). The presence of inactive integrin subunits prior to implantation of the embryo can induce dramatic changes in the uterine endometrium through post-adhesion activation of embryos. In this study, specific integrin subunits ( $\alpha_{6}$ and $\alpha_{9}$ in ES cells, and $\alpha_{7}$ and $\alpha_{9}$ in EE cells) were present in an inactive form on the cell membrane, indicating that signals derived from laminin (interacting with heterodimers with integrin $\alpha_{6}$ or $\alpha_{7}$ subunits) and tenascin $C$ (interacting with heterodimers with integrin $\alpha_{9}$ subunits) may be important in the remodeling of ES and EE tissue following embryo contact with EE cells. This is supported by the endometrial identification of laminin and tenascin C during pregnancy (Michie \& Head 1994, Kaloglu \& Onarlioglu 2010). Accordingly, research on the expression of inactive integrin subunits in specific cells may be useful in the generation of specific microenvironments.

In conclusion, the co-expression of integrin $\alpha_{2} \beta_{1}$, $\alpha_{5} \beta_{1}, \alpha_{v} \beta_{1}, \alpha_{v} \beta_{3}$ and $/$ or $\alpha_{v} \beta_{5}$, and integrin $\alpha_{2} \beta_{1}, \alpha_{5} \beta_{1}, \alpha_{6} \beta_{1}$ and/or $\alpha_{6} \beta_{4}, \alpha_{v} \beta_{1}, \alpha_{v} \beta_{3}$ and/or $\alpha_{v} \beta_{5}$, on the surface of ES and EE cells derived from mouse endometrium in estrus, respectively, was confirmed. Integrin $\alpha_{6}$ and $\alpha_{9}$ or $\alpha_{7}$ and $\alpha_{9}$ were also identified as individual subunits on the membranes of ES or EE cells. Identification of the integrin heterodimers or subunits expressed on ES 
and EE cells will be useful for determining the type of ECM analogs that specifically activate each integrin heterodimer to generate synthetic niches to represent endometrial tissue in vivo. Moreover, the generation of synthetic endometrial tissue based on this knowledge will contribute to our understanding of the mechanism of implantation, and aid in the study of uterine receptivity and endometrial hormonal responses.

\section{Declaration of interest}

The authors declare that there is no conflict of interest that could be perceived as prejudicing the impartiality of the research reported.

\section{Funding}

This research was supported by a grant of the Korea Health Technology R\&D Project (HI12C1404(A121515)), Ministry of Health and Welfare, Republic of Korea.

\section{References}

Arai M, Yoshioka S, Tasaki Y \& Okuda K 2013 Remodeling of bovine endometrium throughout the estrous cycle. Animal Reproduction Science 142 1-9. (doi:10.1016/j.anireprosci.2013.08.003)

Arnold JT, Kaufman DG, Seppala M \& Lessey BA 2001 Endometrial stromal cells regulate epithelial cell growth in vitro: a new co-culture model. Human Reproduction 16 836-845. (doi:10.1093/humrep/16.5.836)

Bodary SC \& McLean JW 1990 The integrin beta 1 subunit associated with the vitronectin receptor alpha $v$ subunit to form a novel vitronectin receptor in a human embryonic kidney cell line. Journal of Biological Chemistry 265 5938-5941.

Brizzi MF, Tarone G \& Defilippi P 2012 Extracellular matrix, integrins, and growth factor as tailors of the stem cell niche. Current Opinion in Cell Biology 24 645-651. (doi:10.1016/j.ceb.2012.07.001)

Burghardt RC, Johnson GA, Jaeger LA, Ka H, Garlow JE, Spencer TE \& Bazer FW 2002 Integrins and extracellular matrix proteins at the maternal-fetal interface in domestic animals. Cells, Tissues and Organs 172 202-217. (doi:10.1159/000066969)

Byron A \& Frame MC 2016 Adhesion protein networks reveal functions proximal and distal to cell-matrix contacts. Current Opinion in Cell Biology 39 93-100. (doi:10.1016/j.ceb.2016.02.013)

Chadchan SB, Kumar V, Maurya VK, Soni UK \& Jha RK 2016 Endoglin (CD105) coordinates the process of endometrial receptivity for embryo implantation. Molecular and Cellular Endocrinology 425 69-83. (doi:10.1016/j.mce.2016.01.014)

Chan RW, Schwab KE \& Gargett CE 2004 Clonogenicity of human endometrial epithelial and stromal cells. Biology of Reproduction 70 1738-1750. (doi:10.1095/biolreprod.103.024109)

Delannet M, Martin F, Bossy B, Cheresh DA, Reichardt LF \& Duband JL 1994 Specific roles of the alpha $V$ beta1, alpha $V$ beta 3 and alpha $V$ beta 5 integrins in avian neural crest cell adhesion and migration on vitronectin. Development 120 2687-2702.

Faber M, Wewer UM, Berthelsen JG, Liotta LA \& Albrechtsen R 1986 Laminin production by human endometrial stromal cells relates to the cyclic and pathologic state of the endometrium. American Journal of Pathology 124 384-391.

Fiorilli P, Partridge D, Staniszewska I, Wang JY, Grabacka M, So K, Marcinkiewicz C, Reiss K, Khalili K \& Croul SE 2008 Integrins mediate adhesion of medulloblastoma cells to tenascin and activate pathways associated with survival and proliferation. Laboratory Investigation $\mathbf{8 8}$ 1143-1156. (doi:10.1038/labinvest.2008.89)

Gronthos S, Simmons PJ, Graves SE \& Robey PG 2001 Integrin-mediated interactions between human bone marrow stromal precursor cells and the extracellular matrix. Bone 28 174-181. (doi:10.1016/S87563282(00)00424-5)

Heino J 2007 The collagen family members as cell adhesion proteins. BioEssays 29 1001-1010. (doi:10.1002/bies.20636)

Horton MA 1997 The $\alpha v \beta 3$ integrin 'vitronectin receptor'. International Journal of Biochemistry and Cell Biology 29 721-725. (doi:10.1016/ S1357-2725(96)00155-0)

Hynes RO 2009 The extracellular matrix: not just pretty fibrils. Science $\mathbf{3 2 6}$ 1216-1219 (doi:10.1126/science.1176009)

Jokimaa V, Oksjoki S, Kujari H, Vuorio E \& Anttila L 2002 Altered expression of genes involved in the production and degradation of endometrial extracellular matrix in patients with unexplained infertility and recurrent miscarriages. Molecular Human Reproduction 12 1111-1116. (doi:10.1093/molehr/8.12.1111)

Julian J, Chiquet-Ehrismann R, Erickson HP \& Carson DD 1994 Tenascin is induced at implantation sites in the mouse uterus and interferes with epithelial cell adhesion. Development 120 661-671.

Kaloglu C \& Onarlioglu B 2010 Extracellular matrix remodelling in rat endometrium during early pregnancy: the role of fibronectin and laminin. Tissue and Cell 42 301-306. (doi:10.1016/j. tice.2010.07.004)

Kao LC, Tulac S, Lobo S, Imani B, Yang JP, Germeyer A, Osteen K, Taylor RN, Lessey BA \& Giudice LC 2002 Global gene profiling in human endometrium during the window of implantation. Endocrinology 143 2119-2138. (doi:10.1210/endo.143.6.8885)

Kikkawa Y, Sanzen N, Fujiwara H, Sonnenberg A \& Sekiguchi K 2000 Integrin binding specificity of laminin-10/11: laminin-10/11 are recognized by alpha3beta1, alpha6beta1 and alpha6beta4 integrins. Journal of Cell Science 113 869-876.

Kim SH, Turnbull J \& Guimond S 2011 Extracellular matrix and cell signaling: the dynamic cooperation of integrin, proteoglycan and growth factor receptor. Journal of Endocrinology 209 139-151. (doi:10.1530/ JOE-10-0377)

Klaffky EJ, Gonzales IM \& Sutherland AE 2006 Trophoblast cells exhibit differential responses to laminin isoforms. Developmental Biology 292 277-289. (doi:10.1016/j.ydbio.2005.12.033)

Koks CA, Groothuis PG, Dunselman GA, de Goeij AF \& Evers JL 2000 Adhesion of menstrual endometrium to extracellular matrix: the possible role of integrin alpha(6)beta(1) and laminin interaction. Molecular Human Reproduction 6 170-177. (doi:10.1093/molehr/6.2.170)

Leppert PC, Jayes FL \& Segars JH 2014 The extracellular matrix contributes to mechanotransduction in uterine fibroids. Obstetrics and Gynecology International 2014 783289. (doi:10.1155/2014/783289)

Lessey BA 1988 Endometrial integrins and the establishment of uterine receptivity. Human Reproduction 13 247-258.

McLean AC, Valenzuela N, Fai S \& Bennett SA 2012 Performing vaginal lavage, crystal violet staining, and vaginal cytological evaluation for mouse estrous cycle staging identification. Journal of Visualized Experiments 15 e4389. (doi:10.3791/4389)

Michie HJ \& Head JR 1994 Tenascin in pregnant and non-pregnant rat uterus: unique spatio-temporal expression during decidualization. Biology of Reproduction 50 1277-1286. (doi:10.1095/biolreprod50.6.1277)

Muller U, Bossy B, Venstrom K \& Reichardt LF 1995 Integrin alpha8 beta1 promotes attachment, cell spreading, and neurite outgrowth on fibronectin. Molecular Biology of the Cell 6 433-448.

Multhaupt HA, Leitinger B, Gullberg D \& Couchman JR 2016 Extracellular matrix component signaling in cancer. Advanced Drug Delivery Reviews 97 28-40. (doi:10.1016/j.addr.2015.10.013)

Nishiuchi R, Takagi J, Hayashi M, Ido H, Yagi Y, Sanzen N, Tsuji T, Yamada M \& Sekiguchi K 2006 Ligand-binding specificities of laminin-binding integrins: a comprehensive survey of lamininintegrin interactions using recombinant alpha3beta1, alpha6beta1, alpha7beta1 and alpha6beta4 integrins. Matrix Biology 25 189-197. (doi:10.1016/j.matbio.2005.12.001)

Pan L, Zhao Y, Yuan Z \& Qin G 2016 Research advances on structure and biological functions of integrins. Springerplus 5 1094. (doi:10.1186/ s40064-016-2502-0)

Park KR, Inoue T, Ueda M, Hirano T, Higuchi T, Maeda M, Konishi I, Fujiwara H \& Fujii S 2000 CD9 is expressed on human endometrial epithelial cells in association with integrins alpha(6), alpha(3) and beta(1). Molecular Human Reproduction 6 252-257. (doi:10.1093/ molehr/6.3.252) 
Ponsuksili S, Murani E, Schwerin M, Schellander K, Tesfaye D \& Wimmers K 2012 Gene expression and DNA-methylation of bovine pretransfer endometrium depending on its receptivity after in vitroproduced embryo transfer. PLOS ONE 7 e42402. (doi:10.1371/journal. pone.0042402)

Reddy KV \& Mangale SS 2003 Integrin receptors: the dynamic modulators of endometrial function. Tissue and Cell 35 260-273. (doi:10.1016/ S0040-8166(03)00039-9)

Rosso F, Giordano A, Barbarisi M \& Barbarisi A 2004 From cell-ECM interactions to tissue engineering. Journal of Cellular Physiology 199 174-180. (doi:10.1002/jcp.10471)

Sanchez-Aparicio P, Dominquez-Jimenez C \& Garcia-Pardo A 1994 Activation of the alpha4 beta1 integrin through the beta1 subunit induces recognition of the RGDS sequencing in fibronectin. Journal of Cell Biology 126 271-279.

Schaefer L \& Reinhardt DP 2016 Special issue: extracellular matrix: therapeutic tools and targets in cancer treatment. Advanced Drug Delivery Reviews 97 1-3. (doi:10.1016/j.addr.2016.01.001)

Schwab KE, Chan RW \& Gargett CE 2005 Putative stem cell activity of human endometrial epithelial and stromal cells during the menstrual cycle. Fertility and Sterility 84 1124-1130. (doi:10.1016/j. fertnstert.2005.02.056)

Seguin L, Desgrosellier JS, Weis SM \& Cheresh DA 2015 Integrins and cancer: regulators of cancer stemness, metastasis, and drug resistance. Trends in Cell Biology 25 234-240. (doi:10.1016/j.tcb.2014.12.006)

Strauss JF 2013 Extracellular matrix dynamics and fetal membrane rupture. Reproduction Sciences 20 140-153. (doi:10.1177/ 1933719111424454)

Su Y, Xia W, Li J, Walz T, Humphries MJ, Vestweber D, Cabanas C, Lu C \& Springer TA 2016 Relating conformation to function in integrin $\alpha 5 \beta 1$. PNAS 113 E3872-E3881. (doi:10.1073/pnas.1605074113v)

Tang M, Xu Y, Julian J, Carson D \& Tabibzadeh S 2005 Lefty is expressed in mouse endometrium in estrous cycle and periimplantation period. Human Reproduction 20 872-880. (doi:10.1093/ humrep/deh717)

Theocharis AD, Skandalis SS, Gialeli C \& Karamanos NK 2016 Extracellular matrix structure. Advanced Drug Delivery Reviews 97 4-27. (doi:10.1016/j.addr.2015.11.001)
Veqa ME \& Schwarzbauer JE 2016 Collaboration of fibronectin matrix with other extracellular signals in morphogenesis and differentiation. Current Opinion in Cell Biology 42 1-6. (doi:10.1016/j.ceb.2016.03.014)

Vitillo L, Baxter M, Iskender B, Whiting P \& Kimber SJ 2016 Integrinassociated focal adhesion kinase protects human embryonic stem cells from apoptosis, detachment, and differentiation. Stem Cell Reports 7 167-176. (doi:10.1016/j.stemcr.2016.07.006)

Yamada O, Todoroki J, Takahashi T \& Hashizume K 2002 The dynamic expression of extracellular matrix in the bovine endometrium at implantation. Journal of Veterinary Medical Science 64 207-214. (doi:10.1292/jvms.64.207)

Yokosaki Y, Palmer EL, Prieto AL, Crossin KL, Bourdon MA, Pytela R \& Sheppard D 1994 The integrin alpha9 beta1 mediates cell attachment to a non-RGD site in the third fibronectin type III repeat of tenascin. Journal of Biological Chemistry $26926691-26696$.

Wayner EA, Orlando RA \& Cheresh DA 1991 Integrins alpha v beta 3 and alpha $v$ beta 5 contribute to cell attachment to vitronectin but differentially distribute on the cell surface. Journal of Cell Biology 113 919-929.

White DJ, Puranen S, Johnson MS \& Heino J 2004 The collagen receptor subfamily of the integrins. International Journal of Biochemistry and Cell Biology 36 1405-1410. (doi:10.1016/j.biocel.2003.08.016)

Zhang C, Duan E, Cao Y, Jiang G \& Zeng G 2000 Effect of 32/67 kDa laminin-binding protein antibody on mouse embryo implantation. Journal of Reproduction and Fertility 119 137-142. (doi:10.1530/ jrf.0.1190137)

Znoyko I, Trojanowska M \& Reuben A 2006 Collagen binding alpha2beta1 and alpha1beta1 integrins play contrasting roles in regulation of Ets-1 expression in human liver myofibroblasts. Molecular and Cellular Biochemistry 282 89-99. (doi:10.1007/s11010-006-1400-0)

Received 20 September 2016

First decision 6 October 2016

Revised manuscript received 23 November 2016

Accepted 19 December 2016 